\title{
Partisipasi Masyarakat Kecamatan Kalibawang dalam Gerakan “Bela-Beli Kulon Progo"
}

\author{
FELIX ARBERD NUR KRISTIANTO \\ Fakultas Ilmu Sosial UNY \\ e-mail: felixarberd@gmail.com
}

\begin{abstract}
Abstrak
Penelitian ini bertujuan mengetahui partisipasimasyarakat Kecamatan Kalibawang dalam Gerakan "Bela-Beli Kulon Progo" beserta faktor pendukung dan penghambatnya. Penelitian ini menggunakan metode deskriptif kualitatif dengan informanyaitu Bupati;Kepala Dinas Koperasi dan UMKM, Kepala Bagian Industri Disperindag dan ESDM, Kepala Bagian Tanaman Pangan Dinas Pertanian dan Kehutanan, Staf bagian TI dan Humas, Staf Bagian Pengkajian Teknologi Pertanian Kantor KP4K, Kabupaten Kulon Progo serta Staf Bagian Keuangan, Staf Bagian Ekonomi Pembangunan, Pengumpul Pengolah Penyaji Data Pertanian (P3D) staf KP4K; Penyuluh pertanian staf Dinas Pertanian dan Kehutanan, Kecamatan Kalibawang; Ketua kelompok tani; dan masyarakat. Pengumpulan data dengan wawancara, observasi, dan dokumentasi. Keabsahan data menggunakan triangulasi sumber. Analisis data menggunakan analisis interaktif. Hasil penelitian: (1) Partisipasi masyarakat sudah kelihatan tetapi belum optimal, (2)Bentuk kegiatan partisipasi masyarakat adalah dalam menggerakkan sumber daya masyarakatnya, (3)Bentuk partisipasinya tergolong partisipasi mandiri,(4)Terdapat beberapa faktor pendukung dan penghambat partisipasi masyarakat dalam Gerakan "Bela-Beli Kulon Progo".
\end{abstract}

Kata Kunci:Partisipasi Masyarakat, Gerakan “Bela-Beli Kulon Progo"

\section{Abstract}

This research aims to know the public participation of Kalibawang Sub District in "Bela-Beli Kulon Progo" movement along with its supporting factors and obstacles. The research design utilizes qualitative descriptive method. Informants for this research are the Regent of Kulon Progo, Head of Cooperative and SMEs of Kulon Progo Regency, Head of Industrial Division from Department of Trade and Industry and Energy and Mineral Resources of Kulon Progo Regency, Head of Food Crops Agriculture and Forestry Department of Kulon Progo Regency, Staff of Information Technology and Public Relation of Kulon Progo Regency, Staff of Agricultural Technology Assessment from the Office of Food Security Agricultural Counselling and Fisheries and Forestry (KP4K), Finance Division of Kalibawang Sub District, Staff of Economic Development of Kalibawang Sub District, Collector Processor and Renderer of Agricultural Data (P3D) KP4K staff in Kalibawang Sub District, Agricultural Counsellor Staff of Agriculture and Forestry Department of Kulon Progo Regency in Kalibawang Sub District, Chief of the Community and Farmer Group of Kalibawang Sub District, and Kalibawang Sub District society. The data collection techniques consist of interviews, observasions, and documentations. Validity of the data utilizes source triangulation. The data analysis technique employs interactive analysis. The research findings are (1) Public participation in Kalibawang Sub District has existed but it not optimal yet (2) The form of public participation activity is mobilizing the human resources (3) The public participation belongs to selfmobilization (4) There are several supporting factors and obstacles in public participation of "Bela-Beli Kulon Progo" movement in Kalibawang Sub District.

Keywords: Public participation, Bela-Beli Kulon Progo movement. 


\section{PENDAHULUAN}

Kulon Progo merupakan Kabupaten di DIY yang menduduki peringkat dua terakhir dalam kesejahteraan masyarakatnya. Hal ini dapat dilihat dari Indeks Pembangunan Manusia (IPM) pada tahun 2013 mencapai 75,95, terendah setelah Kabupaten Gunung Kidul dengan IPM mencapai 71,64 (BPS DIY, 2014: 254). Sebenarnya Kabupaten Kulon Progo memiliki banyak potensi sumber daya alam yang dapat dimanfaatkan untuk mendongkrak perekonomian dan meningkatkan kesejahteraan masyarakat. Sektor pertanian masih menjadi andalan perekonomian Kabupaten Kulon Progo. Pada tahun 2009 sumbangan sektor ini sebesar 24,11 \% (BPS Kulon Progo, 2009:27).

Beberapa program penanggulangan kemiskinan yang terlaksana di Kabupaten Kulon Progo sudah selaras dengan RPJMD tapi belum mampu menekan angka kemiskinan yang masih tinggi. Ketidakberhasilan program-program penanggulangan menunjukan bahwa kemiskinan adalah masalah kompleks. Maka dari itu, lahirlah semangat yang disebut Gerakan "Bela-Beli Kulon Progo" sebagai bentuk usaha penanggulangan kemiskinan yang melibatkan partisipasi masyarakat. Gerakan "Bela-Beli Kulon Progo" merupakan gerakan sosial yang dirintis oleh Pemerintah Kabupaten Kulon Progo dengan berlandaskan aspek pemberdayaan masyarakat dalam RPJMD.

Di sisi lain kemiskinan bukan hanya menjadi masalah pemerintah saja. Pemecahan masalah kemiskinan tidak dapat lagi dilakukan oleh pemerintah sendiri melalui kebijakan terpusat dan berjangka pendek, melainkan memerlukan pendekatan terpadu, terencana, berkesinambungan, dan menuntut keterlibatan banyak pihak (Sekretariat Tim Pengendali PNPM, 2008:4). Kemiskinan muncul karena kurangnya partisipasi masyarakat dalam penanggulangan kemiskinan.

Kecamatan Kalibawang merupakan salah satu kecamatan dengan kategori miskin di Kabupaten Kulon Progo. Kecamatan Kalibawang memiliki $5663 \mathrm{KK}$ miskin dengan katagori KK pra KS berjumlah 3498 KK dan
KS-1 2168 KK (BPS Kulon Progo, 2014: 82). Untuk menekan angka kemiskinan ini, sebenarnya Kecamatan Kalibawang memiliki potensi pertanian yang bisa dioptimalkan. Program ini adalah salah satu jalan untuk mengoptimalkan potensi yang dimiliki oleh Kecamatan Kalibawang.

Dengan melihat angka kemiskinan yang tinggi, penanggulangan kemiskinan telah menjadi perhatian pemerintah Kabupaten Kulon Progo (BPS Kulon Progo, 2012:54). Adapun, program pemerintah pusat bekerja sama dengan pemerintah daerah dalam penanggulangan kemiskinan sepertiberas untuk KK miskin (raskin) di 12 kecamatan setiap bulannya sudah berjalan, tapi raskin berakhir pada bulan Oktober 2014 karena pemerintahan Presiden Susilo Bambang Yudhoyono sudah berakhir sehingga tidak ada alokasi raskin untuk bulan November dan Desember 2014 (Iskandar, 2014), Bantuan Langsung Sementara Masyarakat (BLSM) adalah bantuan dari pemerintah kepada RTM dalam rangka kompensasi pengurangan subsidi bahan bakar minyak (BBM), program berjalan tapi banyak yang tidak tepat sasaran, program Rumah Tidak Layak Huni (RTLH)/ bedah rumah ini tidak berjalan dengan baik karena tidak menyasar warga yang sebenarnya masuk dalam sasaran program itu karena faktor administrasi (Atamsari, 2014), dan kelompok Usaha Bersama (KUBE) adalah program dari Kementerian Sosial RI untuk memberdayakan kelompok masyarakat miskin dengan pemberian modal usaha melalui program Bantuan Langsung Pemberdayaan Sosial untuk mengelola Usaha Ekonomi Produktif (UEP) (Roni, 2011). Pada tahun 2012, sebanyak 95 kelompok usaha menerima bantuan 1,9 milyar rupiah. Masing-masing kelompok menerima 20 juta untuk mengembangkan usaha produktifnya (Arasyid, 2012).

Sedangkan beberapa program Pemerintah Kabupaten Kulon Progo untuk menanggulangi kemiskinan seperti Program Pengurangan Pekerja Anak - Program Keluarga Harapan (PPA-PKH) adalah program untuk mengurangi kemiskinan dengan memberikan bantuan akses pendidikan pada anakanak, pada tahun 2014, 90 anak Kulon Progo 
mengikuti program ini (Widiastuti, 2014), selanjutnya, program Posdaya (Pos Pemberdayaan Keluarga) adalah forum kebersamaan yang anggotanya melakukan aktivitas nyata dalam gerakan pembangunan di lingkungan paling bawah (RT, RW, Dukuh, dan Dusun), masyarakat diarahkan untuk menghidupkan kembali budaya gotong royong dengan melibatkan kegiatan pemberdayaan keluarga di bidang pendidikan, kesehatan, dan ekonomi sesuai dengan potensi masingmasing wilayah (www.web.ipb.ac.id, 2009). Berdasarkan observasi, partisipasi masyarakat dalam program Posdaya masih belum berjalan secara optimal terbukti tidak di semua desa memiliki Posdaya karena hanya pedukuhan-pedukuhan di desa tertentu saja yang aktif, selain itu faktor pemimpin masyarakat menentukan dalam pembentukan posdaya itu sendiri. Program selanjutnya adalah program KAKB (Kelompok Asuh Keluarga Binangun), KAKB memiliki konsep pemberdayaan dengan prinsip keluarga sejahtera mengasuh keluarga pra sejahtera (Media Center Kabupaten Kulon Progo, 2014). Program KAKB sudah berjalan tapi masih sebatas inisiatif menjalankan program, belum ada perencanaan yang jelas dan belum bisa mengatasi masalah kemiskinan (Sutarmi, 2014).

Beberapa program penanggulangan kemiskinan yang terlaksana di Kabupaten $\mathrm{Ku}-$ lon Progo sudah selaras dengan RPJMD tapi belum mampu menekan angka kemiskinan yang masih tinggi. Ketidakberhasilan program-program penanggulangan menunjukan bahwa kemiskinan adalah masalah kompleks. Maka dari itu, lahirlah semangat yang disebut Gerakan "Bela-Beli Kulon Progo" sebagai bentuk usaha penanggulangan kemiskinan yang melibatkan partisipasi masyarakat. Gerakan "Bela-Beli Kulon Progo" merupakan gerakan sosial yang dirintis oleh Pemerintah Kabupaten Kulon Progo dengan berlandaskan aspek pemberdayaan masyarakat dalam RPJMD. Bupati Kulon Progo, dr.H. Hasto Wardoyo,Sp.OG(K) bersama Forum Komunikasi Informatika Daerah (Forkompinda), dan ribuan masyarakat mendeklarasikan Ikrar Gerakan "Bela-Beli Kulon Progo" di Alun-alun Wates pada tanggal 25 Maret 2013. (Media
Center Kabupaten Kulon Progo, 2013). Gerakan ini bertujuan meningkatkan partisipasi masyarakat dalam membeli produk asli Kabupaten Kulon Progo sebagai bentuk membela Kulon Progo untuk meningkatkan kesejahteraaan masyarakatnya.

Dengan potensi daerah yang dimiliki, Kabupaten Kulon Progo ingin mengoptimalkannya sehingga mampu menekan angka kemiskinan dan meningkatkan kesejahteraan masyarakatnya. Tujuan lain dari Gerakan "Bela-Beli Kulon Progo" adalah melibatkan partisipasi masyarakat agar lebih kreatif dan inovatif dalam mengembangkan dan memasarkan produk khas daerah yang mempunyai daya saing. Adapun produk-produk asli Kabupaten Kulon Progo yang mempunyai daya saing di pasar seperti gula semut berasal dari Kecamatan Kokap, batik "geblek renteng" berasal dari Kecamatan Lendah, durian Menoreh Kuning hasil pertanian Kecamatan Kalibawang, dan teh Surolo yang berasal dari Pegunungan Suroloyo.

Perspektif pembangunan yang menggunakan pendekatan pemberdayaan sudah cukup lama mendapat giliran arus utama pemikiran dan landasan kebijakan pembangunan masyarakat di negara-negara berkembang (Soetomo, 2013:5). Sesuai dengan arah pembangunan Kabupaten Kulon Progo yang tertuang dalam RPJMD maka yang dibutuhkan saat ini adalah sebuah kebijakan yang lebih memberdayakan masyarakat. Gerakan "Beli Kulon Progo" merupakan salah satu bentuk kebijakan yang menekankan pemberdayaan masyarakat. Program ini memiliki gagasan perubahan dari bawah dan diharapkan dapat menanggulangi kemiskinan dan melibatkan partisipasi aktif masyarakat Kabupaten Kulon Progo, secara khusus masyarakat Kecamatan Kalibawang.

Partisipasi masyarakat Kecamatan Kalibawang dalam Gerakan "Bela-Beli Kulon Progo" ini nyata. Masyarakat Kecamatan Kalibawang tergabung dalam kelompokkelompok tani mempunyai peran mensuplai beras kebutuhan Pegawai Negeri Sipil (PNS) PemKab Kulon Progo setiap bulan. PNS dianjurkan Bupati Kulon Progo untuk membeli beras dari petani Kulon Progo sendiri sesuai 
semangat Gerakan "Bela-Beli Kulon Progo". Selain itu, ada juga kelompok tani yang dipercaya Pemerintah Kabupaten Kulon Progo untuk menanam varietas padi Melati Menoreh (Menor). Padi Menor adalah jenis baru, varietas asli Kulonprogo yang belum pernah dibudidayakan secara massal. Diharapkan bisa menyaingi kualitas premium beras impor.Penanaman perdana dilakukan Bupati Kulonprogo, dr.H. Hasto Wardoyo Sp.OG(K) bersama Ketua MPR RI, Sidarto Danusubroto di persawahan Desa Banjararum, Kecamatan Kalibawang pada September 2013 (Widiyanto, 2013). Sebelum adanya Gerakan "Bela-Beli Kulon Progo" potensi pertanian di Kecamatan Kalibawang belum diolah secara optimal tetapi sesudah adanya program ini ada usaha dari pemerintah untuk mengoptimalkan potensi yang dimiliki. Selain itu, program ini menjadikan semangat tersendiri bagi masyarakat untuk meningkatkan taraf hidupnya.

Namun demikian, berdasarkan observasi yang dilakukan oleh peneliti, partisipasi masyarakat dalam Gerakan "Bela-Beli Kulon Progo" ini belum optimal terbukti hanya kelompok-kelompok tertentu yang terlibat. Program ini belum melibatkan partisipasi masyarakat secara luas sehingga dampaknya pun belum signifikan dalam menekan angka kemiskinan dan meningkatkan kesejahteraan masyarakatnya.Berdasarkan beberapa hal di atas, maka perlu dilakukan suatu kajian mendalam untuk mengetahui partisipasi masyarakat Kecamatan Kalibawang dalam Gerakan "Bela-Beli Kulon Progo" sehingga diharapkan akan diperoleh suatu kesimpulan dan rekomendasi yang dapat digunakan sebagai arahan kebijakan yang mampu menanggulangi kemiskinan dan melibatkan partisipasi masyarakat.

Tujuan dalam penelitian ini adalah:

1. Untuk mengetahui partisipasi masyarakat Kecamatan Kalibawang dalam Gerakan "Bela-Beli Kulon Progo".

2. Untuk mengetahui faktor pendorong dan penghambat partisipasi masyarakat Kecamatan Kalibawang dalam Gerakan "Bela-Beli Kulon Progo".

\section{METODE}

Peneliti menggunakan metode penelitian deskriptif kualitatif. Penelitian ini berlangsung dari 24 November sampai dengan 31 Desember 2014 di Kecamatan Kalibawang. Dalam penelitian ini, peneliti bertindak sebagai instrumen utama. Teknik pengumpulan data dengan wawancara, observasi, dan dokumentasi. Peneliti menggunakan teknik keabsahan data dengan triangulasi sumber.

Informan penelitian yaitu Bupati Kulon Progo, Kepala Dinas Koperasi dan UMKM Kabupaten Kulon Progo, Kepala Bagian Industri Disperindag dan ESDM Kabupaten Kulon Progo, Kepala Bagian Tanaman Pangan Dinas Pertanian dan Kehutanan Kabupaten Kulon Progo, Staf bagian Teknologi Informasi (TI) dan Humas Kabupaten Kulon Progo, Staf Bagian Pengkajian Teknologi Pertanian Kantor Ketahanan Pangan Penyuluhan Pertanian Perikanan dan Kehutanan (KP4K), Staf Bagian Keuangan Kecamatan Kalibawang, Staf Bagian Ekonomi Pembangunan Kecamatan Kalibawang, Pengumpul Pengolah Penyaji Data Pertanian (P3D) staf KP4K di Kecamatan Kalibawang, Penyuluh pertanian staf Dinas Pertanian dan Kehutanan Kabupaten Kulon Progo di Kecamatan Kalibawang, Ketua kelompok tani, dan masyarakat Kecamatan Kalibawang.

Teknik analisis data menggunakan 4 tahap yaitu pengumpulan data, reduksi data, penyajian data, penarikan kesimpulan.

\section{HASIL DAN PEMBAHASAN}

Dalam pembahasan ini, penulis menggunakan 3 indikator Slamet (lewat Mardikanto dan Soebito,2013:91)untuk mengetahui partisipasi masyarakat Kecamatan Kalibawang dalam Gerakan "Bela-Beli Kulon Progo". 3 indikator itu adalah kesempatan partisipasi, kemampuan partisipasi, dan kemauan partisipasi:

Kesempatan Partisipasi

Peran SKPD sangat menentukan keterlibatan partisipasi masyarakat Kecamatan Kalibawang dalam Gerakan "Bela-Beli Kulon Progo". Secara khusus pihak yang terlibat dalam partisipasi masyarakat Kalibawang 
adalah Dinas Pertanian dan Kehutanan Kabupaten Kulon Progo, Disperindag dan ESDM Kabupaten Kulon Progo, KP4K Kabupaten Kulon Progo, aparatur Kecamatan Kalibawang. Dinas Pertanian dan Kehutanan mempunyai peran untuk mengoptimalkan hasil pertanian Kecamatan kalibawang dan melibatkan kelompok tani Ngudi Rejeki dalam penanaman padi Menor, padi khas Kulon Progo. Dari Disperindag dan ESDM mempunyai peran dalam mempersiapkan produk petani Kalibawang agar siap dikonsumi oleh masyarakat Kulon Progo. Dari pihak KP4K Kabupaten Kulon Progo yang mengungkapkan perannya untuk meningkatkan kapasistas petani dengan mendampingi kelompok tani. Humas Kabupaten Kulon Progo mempunyai peran mensosialisasikan program ini melalui media cetak maupun elektronik. Sedangkan Aparatur Kecamatan Kalibawang mempunyai peran menyediakan fasilitas masyarakat yang ingin mempromosikan hasil produknya, melalui pameran yang diselenggarakan pemerintah Kabupaten. Pada intinya, dari peran SKPD tersebut, masyarakat Kalibawang mendapatkan kemudahan akses dalam Gerakan "Bela-Beli Kulon Progo" ini. Kemudahan akses ini dalam rangka meningkatkan produktifitas hasil pertanian masyarakatnya.

Banyak sekali informasi yang didapatkan oleh masyarakat Kalibawang terkait Gerakan "Bela-Beli Kulon Progo" yaitu melalui kunjungan kerja Bupati, melalui perangkat Kecamatan, melalui SKPD dengan tupoksinya dan fungsinya dan juga melalui Humas dan Media Center Kabupaten Kulon Progo. Pak Eko Nugroho adalah ketua gapoktan Asri Lestari mendapatkan informasi tentang "Bela-Beli Kulon Progo" dari kunjungan Bapak Bupati dan tabloid Binangun yang dikeluarkan oleh Humas dan Media Center Kabupaten Kulon Progo.

Masyarakat mendapatkan fasilitas terkait partisipasinya untuk menghasilkan produk berkualitas dalam program ini. Masyarakat mendapatkan fasilitas pada kelompok-kelompok tani seperti bibit, pupuk, dan embung untuk mengairi lahannya. Kecamatan Kalibawang yang menjadi sentra bagi pengembangan tanaman durian dan kakao berdampak bagi kelompok tani karena mendapatkan fasilitas dari pemerintah guna menunjang produktifitasnya. Fasilitas tidak hanya pemberian bibit atau pupuk tapi juga pendampingan intensif kepada kelompokkelompok tani.

Terkait peluang organisasi, dalam program ini partisipasi nyata karena masyarakat sudah memiliki organasasi kelompok tani. Dengan kelompok tani yang sudah teregistrasi oleh KP4K Kabupaten Kulon Progo, partisipasi masyarakat semakin efektif. Hal ini sesuai dengan pendapat Sastropoetro (Karianga, 2011: 244), partisipasi masyarakat akan efektif jika dilakukan oleh organisasi yang sudah ada. Efektif karena program terkait "Bela-Beli Kulon Progo" seperti mensuplai beras untuk PNS dan pemurnian padi Menor bisa berjalan karena memiliki kelompok tani yang siap berpartisipasi dan bekerja sama dengan pemerintah.

Belum ada sistem khusus yang mengatur kerja sama dalam Gerakan "Bela-Beli Kulon Progo". Bupati menjadi pihak yang mengkoordinasikan agar semangat Gerakan "Bela-Beli Kulon Progo" ini sampai pada SKPD masing-masing. Sedangkan implementasi di lapangan sangat cair di masing-masing SKPD. Bentuk koordinasi Bupati kepada SKPD ditanggapi setiap SKPD dalam bentuk implementasi semangat tersebut dalam action. Dari pihak SKPD sudah saling bekerja sama dengan SKPD lainnya jika beririsan dengan tupoksi masing-masing SKPD.

Dari partisipasi masyarakat Kecamatan Kalibawang di atas, penulis menengarai bahwa bentuk partisipasi masyarakat Kalibawang sebagai partisipasi masyarakat yang mandiri seperti yang diungkapkan Pretty (lewat Karianga,2011:223).Bisa dikatakan Partisipasi Mandiri (self mobilization)karena masyarakat Kecamatan Kalibawang mengambil inisiatif sendiri secara bebas (tidak dipengaruhi pihak luar) untuk mengembangkan kontak dengan lembaga-lembaga lain untuk mendapatkan bantuan dan dukungan teknis serta sumberdaya yang diperlukan. Hal itu dibuktikan dengan kerja sama kelompok tani dengan SKPD terkait dalam rangka meminta bantuan fasilitas-fasilitas yang dibutuhkan 
untuk meningkatkan kuantitas dan kualitas produk pertanian. Masyarakat tidak menjadi pihak pasif tapi pihak yang aktif yang mengetahui kebutuhannya dan bagaimana cara mendapatkan kebutuhan itu melalui pihakpihak yang bertanggung jawab

\section{Kemampuan Partisipasi}

Dengan program ini masyarakat Kecamatan Kalibawang memahami adanya peluang untuk meningkatkan taraf hidupnya. Dari kelompok tani mengungkapkan bahwa mendapatkan kemudahan untuk menjual produknya dan juga dari pihak KP4K yang menjelaskan ada penambahan modal bagi kelompok tani. Kelompok tani kakao juga mulai belajar untuk mengolah hasil pertaniannya menjadi permen atau coklat. Hal ini membuktikan bahwa masyarakat memahami akan adanya peluang untuk meningkatkan taraf hidup mereka. Pengetahuan peluang yang dimiliki kelompok tani ini tentu menjadi modal petani meningkatkan kesejahteraannya jika bisa memasarkannya hasil pertaniannya ke PNS dan masyarakat Kulon Progo secara lebih luas.

Kalibawang memiliki potensi pertanian yang besar. Potensi pertanian ini juga didukung oleh regulasi di mana dari pihak pemerintah telah menetapkan bahwa Kecamatan Kalibawang sebagai kawasan perlindungan sehingga lahannya secara khusus difungsikan untuk lahan pertanian. Potensi pertanian yang besar juga karena faktor produktifitas yang signifikan. Produktifitas ini salah satunya dipengaruhi oleh alam di mana curah hujan Kecamatan Kalibawang tergolong tinggi (BPS Kabupaten Kulon Progo, 2013: 201) dan penggunaan lahan-lahan di Kecamatan Kalibawang yang sebagian besar dimanfaatkan untuk pertanian.

Selain produksi pertanian padi atau komoditas beras. Kecamatan Kalibawang juga unggul dalam berbagai tanaman seperti ketela pohon dan tanaman hortikultura seperti, durian, kakao, dan kopi (BPS Kulon Progo, 2014: 202). Di Kalibawang sendiri menjadi sentra atau pusat pengembangan durian dan kakao. Untuk tanaman kakao sendiri, Kalibawang memiliki lahan terluas kedua se-Ku- lon Progo dan menyumbang produksi kakao se-Kulon Progo mencapai 1.043, 87 ton.

Kecamatan Kalibawang memiliki jumlah petani dan kelompok tani yang tergolong banyak. Jumlah Kelompok tani Kecamatan Kalibawang mencapai 160 dengan klasifikasi Kelompok tani untuk pemula 35, lanjut 66 , madya 58, dan utama 1 . Kecamatan Kalibawang memiliki jumlah rumah tangga usaha tani padi, jagung, kedelai, dan tebu sebanyak 4.719 RT. Dari 160 Kelompok tani, mereka tergabung dalam 4 gapoktan yang mandiri dan sudah teregistrasi di KP4K. Dengan potensi yang dimiliki ini tentu menunjukkan partisipasi masyarakat akan lebih condong dalam bidang pertanian.

Terkait indikator kemampuan yang lainnya, masyarakat Kecamatan Kalibawang mampu memecahkan masalah dengan menggunakan sumber daya lain. Kelompok tani durian di Desa Banjaroya memiliki masalah, kurang optimalnya produktifitas durian. Maka dari itu, mereka bekerja sama dengan pemerintah daerah untuk membuat embung guna mengairi lahan pertanian mereka. Akhirnya dana pembuatan embung tersebut didapatkan dari APBD DIY dan bibit duriannya dari CSR Pertamina. Kelompok tani padi juga ketika menghadapi masalah hama di sawahnya meminta bantuan Dinas Pertanian dan Kehutanan untuk membantu menyesaikannya. Jadi, selain dapat disimpulkan bahwa masyarakat Kecamatan Kalibawang mampu memecahkan masalahnya dengan sumber daya lainnya terbukti bahwa partisipasi yang mereka lakukan adalah partisipasi yang mandiri karena mereka mengembangkan kontak dengan sumber daya lain untuk meminta bantuan untuk memenuhi kebutuhannya.

\section{Kemauan Partisipasi}

Selain mengolah hasil pertanian, partisipasi masyarakat juga nyata dalam menggunakan hasil produksi yang dihasilkan oleh masyarakat Kulon Progo sendiri. Ketika ada rapat internal aparatur Kecamatan atau kunjungan Bupati makanan yang disajikan adalah makanan tradisional di sekitar Kalibawang sendiri. PNS seluruh instansi 
pemerintah di Kecamatan Kalibawang juga mengenakan batik "geblek renteng" setiap hari Kamis. Ini membuktikan bahwa arahan Bupati untuk mencintai produk lokal ditanggapi oleh masyarakat Kalibawang. Beberapa PNS di Kalibawang juga menggunakan beras dari gapoktan Kulon Progo. Untuk masyarakat umum, mereka membeli beras di pasar terdekat dan warung sekitar tidak perlu membeli di daerah lainnya. Sebelum adanya program ini, PNS dan masyarakat Kalibawang bisa membeli beras di luar daerah tapi semenjak adanya program ini kesadaran mulai tumbuh karena mereka memilih membeli beras petani lokal.

Aparatur Kecamatan Kalibawang juga menjelaskan bahwa masyarakat sudah paham dengan konsep "Bela-Beli Kulon Progo" karena setiap pertemuan selalu diinformasikan. Dalam program ini, aparatur Kecamatan memberikan teladan kepada masyarakat untuk hidup sederhana seperti saat kunjungan Bupati menghidangkan masakanan tradisional. Tentu hal tersebut sesuai dengan konsep "Bela-Beli Kulon Progo"

Dari program ini, masyarakat Kalibawang sudah bisa membaca peluang bahwa mereka bisa meningkatkan kesejahteraannya. Seperti yang diungkapkan oleh Pak Eko Kurniawan bagian Ekonomi Pembangunan bahwa pemerintah Kecamatan tidak perlu mengarahkan mereka memanfaatkan potensi agrowisata tapi masyarakat sudah bisa membaca peluang dengan membuka usaha kawasan tersebut.

Kemandirian partisipasi dalam Gerakan "Bela-Beli Kulon Progo" juga ditunjukkan oleh kelompok tani yang terlibat dalam mensuplai beras untuk masyarakat luas dan PNS. Partisipasi masyarakat Kecamatan Kalibawang nyata melalui produksi beras oleh Gapoktan Asri Lestari. Gapoktan Asri Lestari memproduksi beras 'sehat' yang pada awalnya di launching bersama Bupati (Media Center Kabupaten Kulon Progo, 2013: 1). Beras sehat ini dikonsumsi masyarakat Kalibawang dan Kulon Progo secara luas.

Di Desa Banjararum, kelompok tani juga terlibat dalam Gerakan "Bela Beli Kulon Progo" dengan mensuplai beras untuk PNS yaitu
Kelompok tani Ngudi Rejeki, Subur, dan Tani Manunggal. Dulu PNS masih banyak yang membeli beras di luar daerah tapi dengan adanya surat edaran Bupati untuk membeli beras petani sendiri, ada kesadaran PNS untuk membeli beras petani Kulon Progo. Kelompok tani di Kalibawang yang mendapatkan peluang untuk mensuplai beras tersebut adalah kelompok tani Subur, Tani Manunggal, dan Ngudi Rejeki. Untuk Kelompok tani Ngudi Rejeki mereka mendapat jatah mensuplai beras ke Dinas Pertanian dan Kehutanan Kabupaten Kulon Progo.

Selanjutnya, partisipasi juga nyata di kelompok tani Ngudi Rejeki, Desa Banjararum dalam proses pemurnian penamaanan padi Melati Menoreh (Menor) padi khas Kulon Progo yang dilaunching pada 13 September 2013 (Media Center Kabupaten Kulon Progo, 2013: 1). Bentuk partisipasi masyarakatnya adalah dalam tahap penamanam sampai paska panen padi Menor ini. Dipilihnya kelompok tani Ngudi Rejeki oleh Dinas Pertanian dan Kehutanan Kabupaten Kulon Progo karena kelompok tani Ngudi Rejeki adalah kelompok tani yang aktif dan mempunyai fasilitas yang siap untuk proses penanaman sampai paska panen.

Dari keterlibatan partisipasi kelompok tani di atas secara khusus kelompok tani Ngudi Rejeki, peneliti menengarai bentuk kegiatan partisipasi yang dilakukan oleh masyarakat Kecamatan Kalibawang adalah dalam menggerakan sumber daya masyarakatnya. Bentuk partisipasi ini sesuai dengan teori dari Dusseldorp (lewat Mardikanto dan Soebito,2013:84) bahwa salah satu bentuk kegiatan partisipasi masyarakat adalah menggerakkan sumber daya masyarakat. Meminjam kata-kata dari Ibu Harmintati selaku Diskop dan UMKM ketika penulis wawancarai bahwa "Bela-Beli Kulon Progo" ini memberikan iklim positif di mana bagi pelaku usaha/petani untuk meningkatkan produktifitasnya dan bagi masyarakat luas ditanamkan pemahaman untuk mencintai produk daerah sendiri. Iklim yang positif dalam usaha ini menggerakan seluruh elemen baik pemerintahan sampai masyarakat Kecamatan Kalibawang untuk meningkatkan 
kuantitas dan kualitas produk pertaniannya.

Selain dari bidang pertanian komoditas padi, Kecamatan Kalibawang juga mempunyai potensi dalam tanaman hortikultura karena menjadi sentra pengembangan tanaman durian dan kakao. Harapannya sentra pengembangan ini bisa menghasilkan daya tarik wisatawan. Dalam rangka pengembangan agrowisata di wilayah Kecamatan Kalibawang banyak potensi agrowisata yang dimiliki Kalibawang seperti embung/ waduk mini yang digunakan untuk mengairi lahan durian $40 \mathrm{Ha}$ dan potensi Desa Banjaroya yang bisa menjadi desa percontohan kakao.

Adapun faktor pendorong dan penghambat partisipasi masyarakat Kecamatan Kalibawang dalam Gerakan "Bela-Beli Kulon Progo" adalah

\section{Faktor Pendorong Partisipasi}

Faktor pendorong partisipasi masyarakat Kecamatan Kalibawang dalam Gerakan "Bela-Beli Kulon Progo" adalah

a. Pertama, sesuai dengan pendapat Adisasmita (2006: 36-37), masyarakat memahami sesungguhnya tentang keadaan lingkungan sosial dan ekonomi mereka sendiri dan mereka mampu memanfaatkan sumber daya pembangunan untuk meningkatkan produksi dan produktifiasnya dalam rangka pembangunan.

b. Kedua, seperti yang diungkapkan Bapak Bupati bahwa program ini adalah sebuah semangat yang dihidupi oleh seluruh elemen masyarakat. Tentu banyak hal yang mempengaruhinya. Program ini mengajak masyarakat untuk membeli produk daerah dan menghasilkan produk daerah berkualitas.Seperti halnya dengan masyarakat Kalibawang yang menemukan peluang untuk meningkatkan taraf hidupnya dari program ini.

c. Ketiga, potensi yang dimiliki dalam hal pertanian menjadikan partisipasi masyarakat Kalibawang ini nyata. Potensi seperti lahan pertanian, kelompok kelompok tani yang terampil mengolah lahan, dan juga hasil yang signifikan bagi pertanian Kulon Progo, Potensi SDA dan SDM inilah yang mendorong keberlang- sungan partisipasi masyarakatnya. Terlebih Kalibawang mempunyai sentra pengembangan komoditas seperti durian dan kakao yang mengundang wisatawan untuk datang.

\section{Faktor Penghambat Partisipasi}

Faktor penghambat partisipasi masyarakat Kecamatan Kalibawang dalam Gerakan "Bela-Beli Kulon Progo" adalah

a. Pertama, tidak ada partisipasi dalam membeli produk lokal, jika perilaku masyarakatnya yang praktis dan boros. Maka dibutuhkan hidup hemat dan sederhana.

b. Kedua, sesuai teori Soetrisno (lewat Mardikanto dan Soebito,2013:95), faktor penghambat partisipasi masyarakat Kalibawang adalah di mana pada tataran perencanaan bahwa partisipasi didefinisikan sebagai kebutuhan masyarakat. Tetapi hal itu belum tentu menjawab kebutuhan masyarakat di lapangan.

c. Ketiga, faktor menghambat partisipasi masyarakat yang lain adalah belum optimalnya dalam pengelolaan potensi agrowisata yang dimiliki Kecamatan Kalibawang.

\section{SIMPULAN}

Partisipasi masyarakat Kecamatan Kalibawang dalam Gerakan "Bela-Beli Kulon Progo" ini sudah kelihatan tapi belum optimal. Partisipasi masyarakat Kecamatan Kalibawang nyata dapat dilihat dari 3 indikator yaitu kesempatan partisipasi, kemampuan partisipasi, dan kemauan partisipasi.

Faktor yang mendorong partisipasi masyarakat Kecamatan Kalibawang dalam Gerakan "Bela-Beli Kulon Progo" adalah masyarakat memahami sesungguhnya tentang keadaan lingkungan sosial dan ekonomi mereka sendiri dan mereka mampu memanfaatkan sumber daya untuk meningkatkan produktifiasnya dalam rangka pembangunan, Masyarakat Kalibawang menyadari bahwa program ini dapat menjawab kebutuhan mereka. Masyarakat Kalibawang bisa menemukan peluang untuk meningkatkan taraf hidupnya, dan sumber daya yang dimil- 
iki yaitu lahan pertanian dan mayoritas penduduknya adalah petani.

Faktor yang menghambat partisipasi masyarakat Kecamatan Kalibawang dalam Gerakan "Bela-Beli Kulon Progo" adalah sikap perilaku masyarakatnya yang praktis dan boros, Perbedaan konsep kesejahteraan menurut masyarakat dan pemerintah terkait dengan tata kelola Raskin Menjadi Rasda, dan belum optimalnya pengelolaan agrowisata yang mempunyai potensi ekonomi untuk menunjang kesejahteraan masyarakatnya.

Berdasarkan hasil penelitian tentang partisipasi masyarakat Kecamatan Kalibawang dalam Gerakan "Bela-Beli Kulon Progo" menunjukkan bahwa partisipasi sudah kelihatan tetapi belum optimal. Hal ini mengandung implikasi bahwa perlu adanya optimalisasi partisipasi. Optimalisasi dapat dilakukan dengan meningkatkan peran pemerintah dalam memberikan informasi program, mendampingi dan meningkatkan kapasitas masyarakat Kecamatan Kalibawang. Harapannya akan terjadi peningkatan partisipasi dan kesejahteraan masyarakat Kecamatan Kalibawang.

Dengan melihat hambatan-hambatan yang terjadi dalam partisipasi masyarakat Kecamatan Kalibawang dalam Gerakan "Bela-Beli Kulon Progo", peneliti memberikan saran sebagai berikut:

1. Perlu adanya penjelasan kepada masyarakat tentang besarnya manfaat ekonomi yang didapatkan masyarakat baik itu langsung maupun tidak langsung. Perlu juga adanya pemahaman bahwa pengembangan partisipasi masyarakat dalam pembangunan pertanian merupakan sebuah investasi sosial yang akan memberikan manfaat jangka panjang dan bukan merupakan sebuah pemborosan. Seperi pemurnian padi Menor, pemerintah sebaiknya menjelaskan manfaatnya kepada masyarakat. Memang saat ini padi Menor masih dalam pemurnian tapi di kemudian hari tentu ada pengakuan dan kepercayaan masyarakat untuk menanamnya karena mengetahui besarnya manfaat bagi kemandirian pangan di Kabupaten Kulon Progo. Sehingga harapannya penanaman padi Menor bisa dilakukan oleh kelompok tani lain dan Kecamatan lainnya.

2. Perlu diadakan sosialisasi yang intensif dan berkelanjutan yang tidak hanya menyampaikan informasi tetapi adanya upaya yang terus menerus untuk meningkatkan kemampuan untuk berpartisipasi. Masyarakat yang mayoritas petani tidak hanya diberikan informasi saja tetapi meningkatkan kapasitasnya dalam Gerakan "Bela-Beli Kulon Progo". Peningkatan kapasitas kelompok tani bisa dilakukan dengan mengajari masyarakat dalam proses pengemasan hasil produksi dan pendampingan dalam penamanan sampai paska tanam yang intensif. Program suplai beras Ke PNS oleh kelompok tani perlu disosialisasikan lagi supaya meningkatkan keterlibatan kelompok tani yang lainnya.

3. Perlu mengoptimalkan potensi agrowisata yang dimiliki Kecamatan Kalibawang karena sudah terbukti banyak wisatawan yang datang untuk melihat hasil pertanian maupun fasilitas yang dimiliki. Harapannya nantinya juga berdampak bagi peningkatan kesejahteraan penduduk sekitar. Optimalisasi agrowisata bisa dengan memberdayakan masyarakat sekitar untuk membuat kerajinan atau produk makanan yang nanti bisa dijual di kawasan agrowisata tersebut.

\section{UCAPAN TERIMA KASIH}

Dalam kesempatan ini penulis mengucapkan terima kasih kepada seluruh pihak yang telah membantu dalam pelaksanaan penelitian, khususnya pihak-pihak yang telah berkenan sebagai informan dalam proses pengambilan data. Penulis juga mengucapkan terima kasih kepada dewan redaksi Jurnal Socia atas kesempatan yang diberikan sehingga paper ini dapat diterbitkan pada Jurnal Socia edisi Mei 2015.

\section{DAFTAR PUSTAKA}

Arasyid, S. 2012. "95 Kelompok Usaha 
Kulon Progo Terima Bantuan 1,9 M".http://economy.okezone.com/ read/2012/11/26/320/723272/95-kelompok-usaha-kulonprogo-terima-bantuan-rp1-9-m/large.Diunduh 23 Oktober2014.

Atamsari, N. 2014. "Bedah Rumah di Kulon Progo dinilai BelumTepatSasaran". http:// jogja.solopos.com/baca/2014/01/27/bedah-rumah-di-kulonprogo-dinilai-belumtepat-sasaran-485157. Diunduh tanggal 16 Oktober 2014

BPS DIY. 2014. Daerah Istimewa Yogyakarta dalam Angka 2014. Yogyakarta: BPS DIY

BPS Kulon Progo. 2009. Kabupaten Kulon Progo dalam Angka.Wates: BPS Kabupaten Kulon Progo

BPS Kulon Progo. 2012. Kabupaten Kulon Progo dalam Angka. Yogyakarta: UD. Sinar Baru Offset

BPS Kulon Progo. 2013. Kecamatan Kalibawang dalam Angka. Wates: BPS Kabupaten Kulon Progo

Iskandar, Y. 2014. "Kulon Progo Tak Punya Raskin Dua Bulan ke Depan". www.tribunnews.com/regional/2014/10/11/kulonprogo-tak-punya-raskin-dua-bulan-kedepan. Diunduh tanggal 15 Oktober 2014

Karianga, H. 2011. Partisipasi Masyarakat dalam Pengelolaan Keuangan Daerah (Persepektif Hukum dan Demokrasi). Bandung: PT. Alumni

Mardikanto, T dan Soebito, P. 2013. Pemberdayaan Masyarakat: dalam Perspektif Kebijakan Publik. Bandung: Alfabeta

Media Center Kabupaten Kulon Progo. 2013. "Padi Asli Kulon Progo Diluncurkan Ketua MPR RI".www.kulonprogokab. go.iddiunduh tanggal 18 Oktober 2014.

Media Center Kabupaten Kulon Progo. 2013. "Padi Asli Kulon Progo Diluncurkan Ketua MPR RI".www.kulonprogokab.go.id Di- unduh tanggal 18 Oktober 2014

Media Center Kabupaten Kulon Progo. 2014. "Penggerak Posdaya 18 Kabupaten Observasi Kulon Progo". http://www. kulonprogokab.go.id/v21/PenggerakPosdaya-18-Kabupaten-Observasi-KulonProgo_3140. Diunduh tanggal 20 Oktober 2014

Roni. 2011. "Profil KUBE". http://www.kemsos.go.id/modules.php?name $=$ News\&file $=$ article $\&$ sid $=16336$. Diunduh tanggal 20 Oktober 2014.

Sekretariat Tim Pengendali PNPM. 2008. Penjelasan dan Tanya Jawab Seputar Program Nasional Pemberdayaan Masyarakat (PNPM) Mandiri. Jakarta: Departemen Kominfo RI

Soetomo. 2013. Pemberdayaan Masyarakat: Mungkinkah Muncul Antitesisnya? Yogyakarta: Pustaka Pelajar

Sutarmi. 2014. "DPRD Diminta Tinjau Ulang Program KAKB". http://jogja.antaranews. com/berita/324412/dprd-diminta-tinjauulang-program-kakb.Diunduh200ktober2014.

Web.ipb.ac.id. 2009. "Pemetaan Perkembangan Posdaya untuk Meningkatkan Kualitas Program Pemberdayaan Masyarakat". http://web.ipb.ac.id/ Ippm/lppmipb/ penelitian/hasilcari.php?status=buka\&id_ haslit=ULTRAPT/002.13/MUL/p. diunduh tanggal 16 Oktober 2014

Widiastuti. 2014. "90 Anak di Kulon Progo Ikuti PPA-PKH". http://krjogja.com/ read/218294/90-anak-di-kulonprogoikuti-ppa-pkh.kr. Diunduh tanggal 16 Oktober 2014.

Widiyanto, D. 2013. "Padi Menor Diluncurkan Pemkab". http://krjogja.com/ read/187047/padi-menor-diluncurkanpemkab.kr diunduh tanggal 14 Oktober 2014. 